\title{
Effect of repeated application of microbial larvicides on malaria transmission in central Côte d'Ivoire
}

\author{
Emile Tchicaya ${ }^{1,2^{*}}$, Benjamin G Koudou ${ }^{1,3,4}$, Jürg Utzinger ${ }^{5}$ \\ From Parasite to Prevention: Advances in the understanding of malaria \\ Edinburgh, UK. 20-22 October 2010
}

The effect of repeated application of Bacillus thuringiensis var israeliensis (Bti) and B. sphaericus (Bs) on different entomological parameters and malaria transmission was investigated in a village in central Côte d'Ivoire. First, all potential mosquito breeding sites identified toward the end of the rainy season in a radius of $1.5-\mathrm{km}$ from the village centre were characterized. Next, we applied Bti $(0.8 \mathrm{mg} / \mathrm{l})$ and, $3-4$ days later, $B s(10 \mathrm{mg} / \mathrm{l})$. The study area was monitored for breeding sites over a 7-month period and microbial larvicides were applied once every $3 \mathrm{wk}$. Additionally, adult mosquitoes were collected inside and outside human habitations in 4 cross-sectional surveys in 2006 using human landing catches. Repeated application of Bti and Bs showed an effect on Anopheles larvae; in 3 of the last 4 surveys no Anopheles larvae were found, whereas before, 6.5-23.7\% of the sites harbored Anopheles larvae. The number of sites positive for Culex larvae decreased after the third treatment round. A total of 2,361 adult mosquitoes were caught in 64 man-night catches; $59.5 \%$ of them belonged to the genus of Anopheles, with An. funestus s.l. being the most abundant species. Entomological transmission parameters recorded for 2006 showed a decline in the biting rate of both An. funestus and An. gambiae compared to the preceding year. Moreover, the entomological inoculation rate of An. funestus was significantly reduced (from 328 to $142 ; P=0.005$ ) whereas that of An. gambiae remained stable. In conclusion, microbial larvicides might play a role in an integrated approach for malaria control.

${ }^{1}$ Centre Suisse de Recherches Scientifques, 01 BP 1303, Abidjan 01, Côte d'Ivoire

(0) 2010 Tchicaya et al; licensee BioMed Central Ltd. This is an open access article distributed under the terms of the Creative Commons Attribution License (http://creativecommons.org/licenses/by/2.0), which permits unrestricted use, distribution, and reproduction in any medium, provided the original work is properly cited.

\section{Author details}

${ }^{1}$ Centre Suisse de Recherches Scientifques, 01 BP 1303, Abidjan 01, Côte d'Ivoire. ${ }^{2}$ UFR Biosciences, Université de Cocody-Abidjan, 22 BP 522, Abidjan 22, Côte d'Ivoire. ${ }^{3}$ Department of Medical Parasitology and Infection Biology, Swiss Tropical Institute, P.O. Box, CH-4002 Basel, Switzerland. ${ }^{4}$ Liverpool School of Tropical Medicine, Liverpool, UK, UFR Sciences de la Nature. ${ }^{5}$ Department of Public Health and Epidemiology, Swiss Tropical Institute, P.O. Box, CH-4002 Basel, Switzerland.

Published: 16 December 2010

\section{doi:10.1186/1475-2875-9-S2-P68}

Cite this article as: Tchicaya et al:: Effect of repeated application of microbial larvicides on malaria transmission in central Côte d'Ivoire. Malaria Journal 2010 9(Suppl 2):P68.

Submit your next manuscript to BioMed Central and take full advantage of:

- Convenient online submission

- Thorough peer review

- No space constraints or color figure charges

- Immediate publication on acceptance

- Inclusion in PubMed, CAS, Scopus and Google Scholar

- Research which is freely available for redistribution 